\title{
The Army Medical Library and Other Medical Libraries of the Nation
}

\section{Mr. Adams is acting librarian, Army Medical Library.}

$\mathrm{J}$ OINT Resolution No. 8 of the FiftySecond Congress, First Session, I892, reads as follows:

Whereas, Large collections illustrative of the various arts and sciences and facilitating literary and scientific research have been accumulated by the action of Congress through a series of years at the national capital; and

Whereas, It was the original purpose of the Government thereby to promote research and the diffusion of knowledge, and is now the settled policy and present practice of those charged with the care of these collections especially to encourage students who devote their time to the investigation and study of any branch of knowledge by allowing them all proper use thereof; and

WHEREAS, It is represented that the enumeration of these facilities and the formal statement of this policy will encourage the establishment and endowment of institutions of learning at the seat of Government, and promote the work of education by attracting students to avail themselves of the advantages aforesaid under the direction of competent instructors: Therefore, be it

Resolved by the Senate and House of Representatives of the United States of America, in Congress assembled, That the facilities for research and illustration in the following and any other Governmental collections now existing or hereafter to be established in the city of Washington for the promotion of knowledge shall be accessible, under such rules and restrictions as the officers in charge of each collection may prescribe, subject to such authority as is now or may hereafter be permitted by law, to the scientific investiga-

1.Paper presented at the Conference of Eastern Col. lege Librarians, Columbia University, Nov. 29, r947. tors and to students of any institution of higher education now incorporated or hereafter to be incorporated under the laws of Congress or of the District of Columbia, to wit:

One. Of the Library of Congress.

Six. Of the Army Medical Museum.

Seven. Of the Department of Agriculture.

I have cited this authority in full because it shows the clear intent of the Congress in encouraging the extension of the services of the federal libraries. Supplemented by a rider to the Appropriation Act for the Geological Survey, I90I, providing for services to "duly qualified individuals, students, and graduates of institutions of learning in the several States and Territories," and by Army Regulation 40-405 describing the Army Medical Library's status and functions, it supports appropriation requests and delimits planning. These documents together form our charter for national service.

Each of the three national libraries has Congressional authority for its services to the nation. The character and degree of such legislated authorities vary. The ambitions of the three libraries are limited, not only by legislative action, but also, as those who have read the Library of Congress budget hearings recognize, by the Congressional committees making appropriations.

Under differing authorities, in different branches of the federal establishment, each of the three libraries has its own problems of national service. Each library has arrived at its present position by a different path; 
each has its own programs, its own public, and its own traditions.

Nevertheless, each is a library performing national services. Can we define this phrase? Are there functions and services which can be exercised only by a federally supported institution? Do they vary in type or in degree from those proper to a private institution? I suggest that the nature and extent of the library services performed for the other libraries of the nation determine this definition. Only with an understanding of what responsibilities have been accepted, what services are offered, and what functions the libraries are actually performing can these questions be answered. The answers inevitably involve the other research libraries of the nation, since to a considerable degree it is through them that the government libraries reach the "scientific investigator" and "duly qualified individuals, students, and graduates of institutions of learning in the several States and Territories."

\section{National Services}

In contributing the Army Medical Library's share to this program, I propose to discuss its national services in three large areas: library resources, bibliographic controls, and public services.

For those who are not familiar with the Army Medical Library and its reorganization, I shall provide first, a brief historical background, and second, a description of the library's setting among the other medical libraries of the country.

The Army Medical Library is the library of the Surgeon General of the Army. Although it was founded in 1836 , it remained a small office library for the use of the Surgeon General until John Shaw Billings took charge of administering surplus hospital funds, officially called the "slush fund," in I 865. From the earliest days Billings had a vision of national service. The Specimen Fasciculus for the Index-Catalogue, published in 1876 , bears the words "National Medical Library" on the title page. In 1879 he founded the Index-Medicus, and in 1880 the first volume of the Index-Catalogue was published. With these publications Billings proposed to provide adequate bibliographical information to the entire medical profession of the United States.

When he left the Army. Medical Library in 1895 , it had become the largest medical library in the country, and although its rate of growth has suffered fluctuations, it has never relinquished this position. Under military appropriation acts, and subject to a rapid turnover of administrators, its fortunes varied. When the World War II came, it was ill-prepared. A survey ordered by the Surgeon General disclosed many deficiencies, and suggested a complete rehabilitation. Acquisitions had slowed down dangerously; the lack of a complete card cata$\log$, a shelflist, even a classification (for Billings believed in shelving broad subject groups without a notation system) made it almost impossible to locate materials. The Index-Catalogue appeared to have strayed from its original purpose; the loan and reference services were not what they should have been. Altogether, the library faced the problem of lifting itself by its boot straps from the nineteenth century into the twentieth.

So much for history. Under Francis R. St. John, and later under Wyllis E. Wright, the first steps were taken. Today the library, still with many inherited defects, is trying to assume the full responsibilities of national service.

\section{Services to a Specialized Group}

As a large special library, the Army Medical Library provides services to a 
specialized group. First, it serves its parent organization, the Office of the Surgeon General; second, government agencies with an interest in medical research; third, the civilian medical libraries of the country; and fourth, the individual civilian physician. It is of course the third group which constitutes for the Army Medical Library "the other research libraries of the nation."

In recent years medical libraries throughout the United States have grown greatly in number and in size. There exists no adequate directory for them. The last $A$ merican Medical Association Directory lists 324 libraries; the Medical Library Association has 253 library members, and Special Library Resources lists some 225 libraries with an interest in medicine. The fact that these statistics must be assembled from such diverse sources demonstrates the differing composition and interests of libraries in the field of medical research. A cross-section will show many types. There are the government libraries: national, such as that of the Public Health Service; state, such as that of the New York State Medical Library; or local, such as that of the Public Health Division, New York City Municipal Reference Library. There are the medical society and association libraries, led by the New York Academy of Medicine and the Boston Medical Library. In the academic world there are the libraries of the university schools of medicine, of pharmacy and dentistry. Then there is a large group of more specialized libraries, the libraries of institutions, foundations, and clinics, libraries of pharmaceutical concerns, and finally, hospital libraries of all descriptions. All of these serve medicine; all of these use the Army Medical Library.

\section{Medical Library Association}

For all of these libraries too, the Medical Library Association provides a meeting ground. This association has had an independent existence dating to 1898 . It is a member of the Council of National Library Associations, an active supporter of the American Book Center. It conducts a successful duplicate exchange; it has an active interest in the improvement of medical bibliography, education for librarianship, international exchange of students, and the betterment of medical library service throughout the country. As its largest member, the Army Medical Library works with and through the association to achieve many common goals. The library is conscious of its responsibilities as the largest member of a specialized national library association. The association looks to the Army Medical Library for service and for leadership.

\section{Resources}

For these medical libraries, the Army Medical Library provides resources beyond those which may be available locally. Such provision is in part a responsibility based on the library's inheritance, and in part a planned continuing action.

The library has over I,00o,ooo titles, I 7,500 of which are serial. Its collection of public health reports, despite many gaps, is unequalled. Its collection of foreign dissertations is most extensive; it holds long runs of editions for the medical classics. With 500 incunabula and 28,000 volumes published before 1800 , its resources for the study of medical history have great depth. Unfortunately, the subject collections for the twentieth century are not so comprehensive; this was a defect noted by the survey.

The Army Medical Library's collection is twice the size of the largest civilian medical library. Its resources have been built through the years with two objectives: first, to make a collection worthy of a national 
medical library, and second, through subject bibliography, to serve medicine.

In 1944 the library drew up a directive for its acqusition policy, defining fields of interest, and setting as an ideal the acquisition of one copy of any work of importance to medical research, regardless of language and date of publication. In carrying out this directive, the library has assumed the responsibility of supplying to agencies of the federal government all library materials in the field of medicine necessary to the national interest. As a corollary the library has accepted responsibility under the Farmington Plan of acquiring these materials in the interest of the private research libraries of the nation.

\section{Bibliographic Controls}

American medicine has a long tradition of being well-served by the systematic indexing and cataloging of its literature. Each of the three comprehensive American indexes covering the entire field of medicine had its origin in the Army Medical Library: The Index-Medicus in 1879 , the IndexCatalogue in 1880 , and the Current List of Medical Literature in 194I. These words from the preface to Vol. I of the IndexMedicus show Billings' interest in current as well as retrospective. medical bibliography:

I have for some time been engaged in preparing an Index-Catalogue of the library of the Surgeon General's Office ... which is intended to show under each subject heading not only the separate books, but all important original articles in medical periodicals and transactions of all countries relating to that subject. ... It has of ten been suggested that it is highly desirable that such a catalogue should be supplemented by some current publication, which would show all recent works, together with articles in periodicals, arranged by subject.

The necessity of supplementing what is perhaps the fullest analytical catalog in book form of any library in the world with a continuing current service existed in 1879 . It still exists today.

The Index-Catalogue, now in its 54th volume and in the middle of its fourth alphabetical series, is the best-known of the library's contributions to medical bibliography. As a reference tool its greatest defect is structural; it cumulates references alphabetically for deferred publication. Thousands upon thousands of important medical references are buried in the Army Medical Library's files awaiting publication at a later date. To be specific: the library maintains a storage file of one and a half million cards; last year the library's public made but $I, 700$ visits to this file. In addition, the Index-Catalogue has altered its form from Billings' original conception and has become a gigantic alphabetical-classed catalog, necessitating intensive application by the user. The tremendous increase of medical literature has slowed its publication in alphabetical series; the next volume will be limited to "M-MEZ." The subject file for the latter part of the fourth alphabet is distended and swollen beyond belief. Material on tuberculosis numbers now some 85,000 references, sufficient to publish a complete volume of detailed subject bibliography. It is no small wonder, therefore, that the surveyors questioned, and the library continues to question, the advisability of continuing the Index-Catalogue in its present form.

The possibility of change and the possibility of coordination with the Quarterly Cumulative Index-Medicus have been long discussed. The director of the library, Colonel Joseph H. McNinch, has proposed that an editorial advisory board be established to consider thoroughly the current needs and techniques of medical bibliography in order to establish policy for the Index-Catalogue and the Current List of 
Medical Literature, and further, that this board be formed in cooperation with the American Medical Association so that the question of the future of the Quarterly Cumulative Index-Medicus might be explored simultaneously. An informal committee met in October to define the problem and to suggest membership for such an advisory board. In anticipation of the inquiries of the board, the library is providing investigation in the field of medical subject bibliography.

There will be no basic changes in the Index-Catalogue or the Current List of Medical Literature until the board has determined policy for the library. The basic question facing the board is that of planning systematically for the library's participation in the effective indexing of the world's medical literature.

The library's contributions to the study of the history of medicine are well-known to the small, but highly active and articulate group of humanistic scholars working in this field. Collections as extensive as those in the library's History of Medicine Division in Cleveland impose upon the library a continuing bibliographic responsibility.

A catalog of the library's 500 medical incunabula, the work of Dorothy Schullian of this division, is in process of publication by Henry Schuman. The Specimen Fasciculus of Dr. Claudius F. Mayer's Biobibliography of 16 th Century Medicine, printed in the Vol. IV of the current series of the Index-Catalogue, shows what may be accomplished in this relatively unexplored field.

The library's incunabula are being microfilmed; once the catalog is published, it will be possible for other libraries and scholars to acquire at the cost of reproduction film covies for their use.

The library's current cataloging activities have a very important meaning for other libraries. Through its contribution to the MED card series published and distributed by the Library of Congress, its new classification and subject headings are becoming known. Close cooperation between the Army Medical Library and the Library of Congress in the field of cooperative cataloging has long been the goal of administrators of both libraries.

In October 1946 an agreement was reached for full cooperation on cataloging between the Army Medical Library and the Library of Congress. The MED card series was announced shortly thereafter, replacing the earlier SGO series. The Army Medical Library has agreed to provide complete card copy for all titles it catalogs for which printed cards are not available; this includes checking of the Library of Congress authority files. The Library of Congress has agreed to accept the simpler forms of descriptive cataloging adopted by the Army Medical Library, and to print the Army Medical Library's copy with the addition of Library of Congress subject headings and classification.

For a full understanding and interpretation of the Army Medical Library's catalog cards in the MED series some attention should be devoted to its rules for descriptive cataloging, its classification, and subject headings. During the period when the library of Congress was developing its recently published rules for descriptive cataloging, the Army Medical Library established its own rules. It had no tradition to respect and could therefore feel free to simplify along pragmatic lines. In order to achieve consistency with Library of Congress practice, it is carefully studying the preliminary edition of Rules for Descriptive Cataloging.

In 1944 a committee of special consultants met to consider a scheme of classification for the medical holdings of the Army Medical Library and the Library of Con- 
gress. At first it was thought possible to develop and revise the " $Q$ " and " $R$ " schedules. As the committee studied the problem it was felt desirable to develop instead the unused letters "QS-QZ" for the preclinical medical sciences, and "W" for clinical medicine and other closely related subjects. The Army Medical Library is a huge special library comprising all of the medical sciences. The Library of Congress is a huge general library comprising all disciplines, including the medical sciences. The one views medicine from the inside; the other from the outside. The " $W$ " classification, prepared for the committee by Mary Louise Marshall, of Tulane, was submitted in draft form to the library during 1946. The library has tested its use, reserving distribution until it has been proved thoroughly practicable. One exception was a concession to the Veterans Administration who wished to use the new classification for its medical libraries. The Veterans Administration published a greatly abbreviated informational outline. The library is now about to publish a preliminary edition of its classification which will be distributed generously; it is hoped that criticism will be equally generous.

As with the Library of Congress schedules, the Army Medical Library's classification is a book classification based on the library's holdings of medical literature. It is not a theoretical classification; it is not designed for the smaller library to follow without interpretation, and it is designed to be used with other L.C. schedules.

In the field of medical subject headings the library is only too conscious that no adequate list exists. Medicine has always been active in nomenclature. The question of standardized systems has been a difficult one. The Army Medical Library is not only building its own list of medical subject headings, but is also encouraging consideration of the many problems on both a philosophic and practical basis. It is important for the library to coordinate its work in medical subject headings with that of the Library of Congress; certainly the confusion resulting from simultaneous use of two lists of medical subject headings is one of the greatest impediments for users of the MED card series.

The foregoing are library activities of national concern in the area of bibliographic controls. They follow from the necessity of making known the contents of the library's vast collections, of guiding research workers to specific information. Their influence extends far beyond the walls of the Army Medical Library. The Index-Catalogue and the Current List index the holdings of other libraries. The MED cards are being used wherever Library of Congress cards go. The "W" classification and the library's subject headings will be considered for adoption by medical libraries of many types.

\section{Public Services}

With the largest collections in the new world at its disposal, and with a long tradition of support for the medical libraries of the country, the Army Medical Library has developed one of the largest interlibrary loan services in the country. Last year the library loaned over 20,000 items throughout the United States. Traditionally it has been generous, restricting service only for older and irreplaceable works. It recognizes its responsibility in making infrequently held and occasionally unique materials freely available to other research libraries, but, since it refers private requests for medical literature back to the local medical libraries, its loan services are clearly defined as supplementary, not competitive. Reading room use of the collections has always been modest. Sixty per cent of the use of materials has been through interlibrary loan and photoduplication. 
These co-existing techniques for making the library's resources generally available to science have developed the use of the collections to an amazing extent. Beginning in I94 I, under the enthusiastic auspices of Dr. Atherton Seidell, the Army Medical Library has experimented with the supply of microfilm in lieu of the loan of publications. Last year $\mathrm{I}, \mathrm{I} 2 \mathrm{O}, 000$ pages were microfilmed; about 80 per cent of this was distributed within the United States. Such use of microfilm is not without problems. We lend to libraries; we supply microfilm to any private investigator, as well as to libraries. In its pure form, as conceived by $\mathrm{Dr}$. Seidell, the use of microfilm in lieu of the loan of books constitutes a gratuitous service of the federal government, subsidizing medical research. There are many arguments for such gratuitous service. It may be argued that it is actually cheaper than a loan. There are also many arguments against it, and not the least of these is lack of statutory authority. In February of this year the library instituted a system of charging for microfilm at cost. The library has provided photoduplication service through the Office of the Publication Board, Department of Commerce, for the Publication Board's reports which have medical interest. Nearly 500,000 pages of these were copied and distributed last year.

It is the field of reference and bibliography in which the Army Medical Library is least adequately organized to provide the type of national service commensurate with its size and materials. In theory, the Army Medical Library should accomplish reference work at a degree of difficulty higher than that of the library it services. It should draw upon and interpret the unusual materials which it has, and which are not generally available. In theory, the library should prepare for publication a series of special subject bibliographies of immediate interest to medicine. In practice, however, three things have militated against this accomplishment. First, is the library's chronic shortage of personnel. It has actually but one part-time bibliographer who can be assigned to the preparation of special lists. Second, is the still disorganized status of the library's collections, which makes it extremely difficult to locate material needed for search of the literature. Third, is the traditional influence of the Index-Catalogue which in itself provides specialized subject bibliographies. The Reference Division was newly formed following the survey and has yet to develop a bibliographic service in its own right. Certainly the Army Medical Library should provide topical bibliographies, as does the Library of Congress and the library of the Department of Agriculture. Medical research cannot wait for the deferred publication of the IndexCatalogue.

In each of these fields-resources, bibliographic controls, and public services-the Army Medical Library serves the country's research libraries. This service is supplementary, not competitive. The library's collections augment the resources of private libraries; the bibliographical activities of the Index-Catalogue, the Current List of Medical Literature, and the Catalog Division interpret these collections, providing services which could not be performed by libraries with smaller resources. Service of the collections through interlibrary loan, photoduplication, and reference by policy and by operation, are extensions of the services offered by the other medical libraries. The Congress, in providing annually appropriated funds for the purchase of materials, for the printing of the Index-Catalogue, in its hearings and reports on a new building for the library, has consistently recognized the national obligations of the institution. 